\title{
Penerapan Algoritma C5.0 Untuk Prediksi Kelulusan Pembelajaran Mahasiswa Pada Matakuliah Arsitektur Sistem Komputer
}

\author{
Muchamad Sobri Sungkar, ${ }^{1, *}$, M Taufik Qurohman² \\ ${ }^{1}$ Teknik Elektronika, Politeknik Harapan Bersama, Jawa Tengah, Indonesia \\ ${ }^{2}$ Teknik Mesin, Politeknik Harapan Bersama, Jawa Tengah, Indonesia \\ Email: 1,* sobrisungkar@gmail.com \\ Email Penulis Korespondensi: sobrisungkar@gmail.com
}

\begin{abstract}
Abstrak-Arsitektur sistem komputer salah satu matakuliah yang wajib diambil pada program studi teknik informatika. Pada program studi kelulusan setiap mahasiswa pada matakuliah merupakan salah satu aspek penting yang harus dilakukan evaluasi pada setiap semesternya. Kelulusan bagi setiap mahasiswa/I pada matakuliah merupakan gambaran bahwasannya proses pembelajaran yang disampaikan berjalan dengan baik dan juga materi yang disampaikan oleh dosen pengampu matakuliah dapat dicerna oleh mahasiswa. Kelulusan setiap mahasiswa pada matakuliah dapat diprediksi berdasarkan dengan pola kebiasaan dari mahasiswa. Data mining merupakan sebuah alternatif proses yang dapat dilakukan untuk mengetahui pola kebiasaan berdasarkan dengan data yang sudah terkumpulkan. Data mining sendiri merupakan proses ekstrasi pada kumpulan data yang menghasilkan informasi berhaga bagi perusahaan, instansi ataupun organisasi yang dapat digunakan dalam proses pengambilan keputusan. Prediksi kelulusan dengan data mining dapat diselesaikan dengan melakukan klasifikasi pada kumpulan data. Algoritma C5.0 merupakan algoritma penyempurnaan dari algoritma C4.5 dimana dalam prosesnya hampir sama, hanya saja algoritma C5.0 punya kelebihan dari algoritma sebelumnya. Hasil pada algoritma C5.0 berupa sebuah pohon keputusan ataupun rule yang dibentuk berdasarkan nilai entropy ataupun gain. Proses prediksi dilakukan berdasarkan dengan klasifikasi algoritma C5.0 dengan menggunakan atribut Nilai Kehadiran, Nilai Tugas, Nilai UTS dan Nilai UAS. Hasil akhir dari proses klasifikasi algoritma C5.0 adalah pohon keputusan dengan rule didalamnya. Kinerja algoritma C5.0 mendapatkan tingkat akurasi yang tinggi sebesar $93,33 \%$
\end{abstract}

Kata Kunci: Data Mining; Prediksi, Kelulusan; Arstektur Sistem Komputer; Algoritma C5.0

Abstract-Computer system architecture is one of the subjects that must be taken in the informatics engineering study program. In the study program the graduation of each student in the course is one of the important aspects that must be evaluated every semester. Graduation for each student / I in the course is an illustration that the learning process delivered is going well and also the material presented by the lecturer in charge of the course can be digested by students. Graduation of each student in the course can be predicted based on the habit pattern of the students. Data mining is an alternative process that can be done to find out habit patterns based on the data that has been collected. Data mining itself is an extraction process on a collection of data that produces valuable information for companies, agencies or organizations that can be used in the decision-making process. Prediction of graduation with data mining can be solved by classifying the data set. The C5.0 algorithm is an improvement algorithm from the $\mathrm{C} 4.5$ algorithm where the process is almost the same, only the $\mathrm{C} 5.0$ algorithm has advantages over the previous algorithm. The results of the C5.0 algorithm are in the form of a decision tree or a rule that is formed based on the entropy or gain value. The prediction process is carried out based on the classification of the C5.0 algorithm by using the attributes of Attendance Value, Assignment Value, UTS Value and UAS Value. The final result of the C5.0 algorithm classification process is a decision tree with rules in it. The performance of the C5.0 algorithm gets a high accuracy rate of $93.33 \%$.

Keywords: Data Mining; Prediction; Graduation; Computer System Architecture; C5.0 Algorithm

\section{PENDAhULUAN}

Arsitektur sistem komputer salah satu matakuliah yang wajib diambil pada program studi teknik informatika. Pada matakuliah arsitektur sistem komputer materi yang dibahas pada proses pembelajaran berkaitan dengan organisasi yang terdapat pada komputer baik struktur dan fungsi setiap komponen, perangkat keras dan perangkat lunak serta kerja dari pada Input Output dan Proses di komputer. Arsitektur sistem komputer adalah matakuliah yang wajib diselesaikan oleh setiap mahasiswa/I. Jika matakuliah arsitektur sistem komputer tidak selesai (gagal) maka tidak diizinkan bagi mahasiswa/I untuk mengambil matakuliah lain yang berkaitan dan kelanjutan dari matakuliah arsitektur sistem komputer.

Pada program studi kelulusan setiap mahasiswa pada matakuliah merupakan salah satu aspek penting yang harus dilakukan evaluasi pada setiap semesternya. Kelulusan bagi setiap mahasiswa/I pada matakuliah merupakan gambaran bahwasannya proses pembelajaran yang disampaikan berjalan dengan baik dan juga materi yang disampaikan oleh dosen pengampu matakuliah dapat dicerna oleh mahasiswa. Selain itu kelulusan mahasiswa/I pada matakuliah akan memenuhi indikator pencapaian yang telah ditentukan oleh program studi. Dimana kelulusan mahasiswa pada matakuliah akan meningkatkan mutu ataupun kualitas bagi program studi tersebut.

Kelulusan setiap mahasiswa pada matakuliah dapat diprediksi berdasarkan dengan pola kebiasaan dari mahasiswa. Dimana pola tersebut dapat dilihat pada data-data mahasiswa yang mengambil matakuliah arsitektir sistem komputer sebelumnya. Pola tersebut dapat dilihat berdasarkan dengan nilai kehadiran, nilai tugas, nilai UTS dan juga nilai UAS. Penerapan teknologi informasi dalam dunia pendidikan juga dapat menghasilkan data yang berlimpah mengenai data mahasiswa dan nilai pembelajaran yang dihasilkan. 
Tentunya pada program studi memiliki data yang begitu banyak berkaitan dengan data kelulusan mahasiswa pada matakuliah arsitektur sistem komputer. Data banyak yang sudah terkumpul tersebut seharusnya dapat dilakukan proses untuk mencari sebuah informasi yang tersimpan pada kumpulan data tersebut. Namun yang menjadi permasalahan adalah masih belum dilakukannya penggalian informasi tersebut bagi program studi ataupun dosen pengampu matakuliah untuk memprediksi kelulusan mahasiswa/I pada matakuliah arsitektur sistem komputer. Hal tersebut dikarenakan belum adanya sebuah proses yang akan dilakukan untuk melakukan proses penggalian data.

Data mining merupakan sebuah alternatif proses yang dapat dilakukan untuk menyelesaikan permasalahan tersebut. Dengan menerapkan proses data mining maka akan memproses seluruh data yang sudah tersimpan di program studi untuk mendapatkan sebuah informasi baru. Data mining sendiri merupakan proses ekstrasi pada kumpulan data yang menghasilkan informasi berhaga bagi perusahaan, instansi ataupun organisasi yang dapat digunakan dalam proses pengambilan keputusan[1]-[6].

Prediksi kelulusan dengan data mining dapat diselesaikan dengan melakukan klasifikasi pada kumpulan data. Klasifikasi merupakan bagian dari pada teknik data mining yang dimana proses dilakukan berdasarkan dengan pengelompokan data. Pengelompokan data pada teknik data mining berdasarkan dengan keterkaitan data terhadap sampel data yang mempunyai kelas label atau target. Salah satu algoritma yang dapat digunakan pada klasifikasi data mining adalah algortima C5.0.

Algoritma C5.0 merupakan algoritma penyempurnaan dari algoritma C4.5 dimana dalam prosesnya hampir sama, hanya saja algoritma C5.0 punya kelebihan dari algoritma sebelumnya. Algoritma C5.0 bagian dari pada teknik klasifikasi pada data mining yang menghasilkan informasi pada bentuk pohon keputusan atau rule. Pembentukan pohon keputusan berdasarkan dari node yang dihasilkan. Pemilihan node pada pohon keputuan algoritma dipilih dari nilai gain dan juga entropy[7].

Algoritma C5.0 banyak digunakan pada penelitian untuk pembahasan klasifikasi. Dibandingkan dengan algoritma klasifikasi lainnya algoritma C5.0 memiliki kinerja lebih baik, selain itu hasil kinerja yang didapatkan dari proses klasifikasi algoritma C5.0 juga memiliki tingkat akurasi yang tinggi[7]-[10].

Pada penelitian ini akan melakukan prediksi kelulusan mahasiswa pada matakuliah arsitektur sistem komputer dengan menerapkan proses data mining dan algoritma C5.0 untuk proses prediksi berdasarkan konsep klasifikasi yang akan dilakukan.

\section{METODOLOGI PENELITIAN}

Metodologi penelitian dijabarkan tahapan-tahapan yang dilakukan dalam penelitian. Metodologi penelitian terdiri dari beberapa tahapan yang terkait secara sistematis. Tahapan ini diperlukan untuk mempermudahkan dalam melakukan penelitian. Sebelum membuat metodologi, penulis terlebih dahulu menganalisa topik yang akan diteliti. Pada analisa penelitian, penulis menjelaskan bagaimana proses penulis dalam pengumpulan data yang diperlukan untuk penelitian ini. Metode pengumpulan data dilakukan dengan cara menggunakan data skunder yang sudah tersedia berdasarkan nilai mahasiswa pada matakuliah arsitektur sistem komputer pada beberapa tahun belakang yang sudah tersimpan di program studi. Secara keseluruhan metodologi penelitian yang dilakukan dapat dilihat pada gambar berikut:

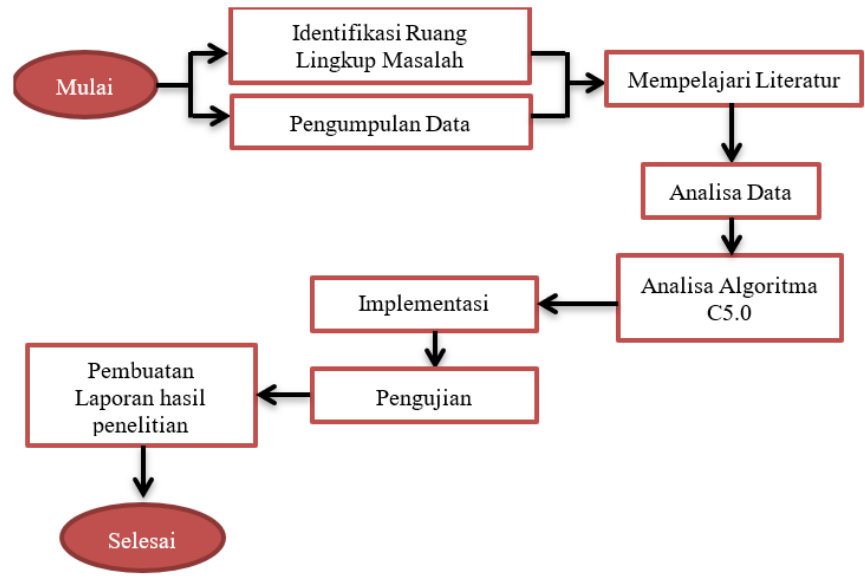

Gambar 1. Metodologi Penelitian

\subsection{Data Mining}

Data mining merupakann upaya untuk menggali informasi yang berharga dan berguna pada database yang sangat besar. Data Mining juga disebut sebagia Knowledge Discovery in Database (KDD) yang dapat diartikan sebagai ekstraksi informasi potensial implisit yang tidak dikenal dari sekumpulan data. Pada proses KDD melibatkan hasil 
proses data mining atau proses mengekstrak kecenderungan suatu pola data, kemudian hasilnya diubah secara tepat menjadi informasi sesuatu yang lebih mudah dipahami[11]-[14].

\subsection{Algoritma C5.0}

Algoritma C5.0 adalah salah satu algoritma yang meruoakan penyempurnaan dari algoritma C4.5 yang menggunkan representasi berbentuk pohon yang setiap node mempresentasikan atribut kemudian cabang mempresentasikan niliai dari atribut dan memiliki yang namanya daun dimana fungsinya adalah kelas. Pengambilan keputusan didasarkan pada nilai Gain terbesar dari hasil perhintungan semua atribut. Berikut adalah langkah-langkah penggunaa algoritma C5.0[15]-[17]:

1. Membuat decission system yang meliputi attribut kondisi dan atribut keputusan. Kemudian memaparkan sebuah decision system yang hanya terdiri dari n objek

2. Menghitung jumlah data kolom, dimana jumlah data tersebut harus berdasarkan anggota atribut tertentu yang hasilnya berdasrkan syarat tertentu.

3. Memilih atribut yang dijadikan sebagai Node.

4. Membuat cabang tiap-tiap anggota Node.

5. Memeriksa apakah nilai entropy tiap anggota Node memiliki nilai nol. Jika didapatkan nilai 0, maka tentukan daun yang telah terbentuk. Jika nilai entropy tiap anggota Node seluruhnya adalah nol, maka proses berhenti.

Anggota node yang memiliki nilai lebih besar dari nol, maka prosesnya diulangi dari awal dengan syarat sampai semua anggota dari Node bernilai nol. Node merupakan atribut yang memiliki nilai gain tertinggi dari atribut-aribut yang ada. Proses menghitung nilai gain suatu atribut harus menggunakan rumus. Berikut adalah rumus untuk menghitung nilai gain yang digunakan di dalam algoritma $\mathrm{C} 4.5$ :

$\operatorname{Gain}(\mathrm{S}, \mathrm{A})=\operatorname{Entropy}(\mathrm{S})-\sum_{i=1}^{n} \frac{|S i|}{|S|}+\operatorname{Entropy}(\mathrm{Si})$

Keterangan dari rumus di atas adalah:

$\mathrm{S}=$ Himpunan Kasus

$\mathrm{A}=$ Atribut

$\mathrm{n}=$ jumlah partisi atribut $\mathrm{A}$

$|\mathrm{Si}|=$ Proporsi Si terhadap $\mathrm{S}$

$|\mathrm{S}|=$ jumlah kasus dalam $\mathrm{S}$

Selain itu rumus untuk menghitung nilai entropy adalah sebagai berikut :

$\operatorname{Entropy}(\mathrm{S})=\sum_{i=1}^{n}-p i+\log _{2} \mathrm{pi}$

Keterangan rumus di atas yaitu :

$\mathrm{S}=$ Himpunan Kasus

$\mathrm{n}=$ jumlah partisi $\mathrm{S}$

$\mathrm{Pi}=$ proporsi Si terhadap $\mathrm{S}$

\section{HASIL DAN PEMBAHASAN}

Sampel data yang akan digunakan untuk melakukan prediksi kelulusan mahasiswa pada matakuliah arsitektur komputer berdasarkan dari data nilai mahasiswa yang sudah tersedia pada program studi. Prediksi nantinya akan dikelompokan menjadi beberapa kriteria pada atributnya. Berikut adalah data kriteria yang akan digunakan untuk proses prediksi kelulusan mahasiswa/i pada matakuliah arsitektur sistem komputer:

Tabel 1. Sampel Data

\begin{tabular}{ccccccc}
\hline No & Responden & Kehadiran & Tugas & UTS & UAS & Hasil \\
\hline 1 & R1 & 100 & 75 & 80 & 85 & Lulus \\
2 & R2 & 100 & 70 & 85 & 80 & Lulus \\
3 & R3 & 93 & 65 & 75 & 50 & Lulus \\
4 & R4 & 86 & 60 & 70 & 50 & Lulus \\
5 & R5 & 100 & 80 & 70 & 60 & Lulus \\
6 & R6 & 79 & 90 & 65 & 50 & Lulus \\
7 & R7 & 71 & 95 & 60 & 65 & Lulus \\
8 & R8 & 93 & 85 & 70 & 75 & Lulus \\
9 & R9 & 64 & 60 & 60 & 0 & Tidak Lulus \\
10 & R10 & 57 & 50 & 50 & 0 & Tidak Lulus \\
11 & R11 & 79 & 70 & 50 & 60 & Lulus \\
12 & R12 & 71 & 65 & 50 & 55 & Tidak Lulus \\
13 & R13 & 50 & 60 & 60 & 0 & Tidak Lulus
\end{tabular}


JURNAL MEDIA INFORMATIKA BUDIDARMA

Volume 5, Nomor 3, Juli 2021, Page 1166-1172

ISSN 2614-5278 (media cetak), ISSN 2548-8368 (media online)

Available Online at https://ejurnal.stmik-budidarma.ac.id/index.php/mib

DOI $10.30865 /$ mib.v5i3.3116

\begin{tabular}{ccccccc}
\hline No & Responden & Kehadiran & Tugas & UTS & UAS & Hasil \\
\hline 14 & R14 & 71 & 75 & 80 & 50 & Lulus \\
15 & R15 & 50 & 50 & 60 & 0 & Tidak Lulus \\
\hline
\end{tabular}

Pada tabel 1 merupakan data nilai dari mahasiswa yang mengambila matakuliah arsitektur sistem computer. Kemudian dari data tersebut sebelum dilakukan proses klasifikasi menggunakan algoritma C5.0 harus dilakukan preprosesing data terlebih dahulu. Preprosesing data dilakukan agar data yang digunakan pada penelitian agar sesuai untuk proses yang akan dilakukan pada algoritma. Data yang sudah dikumpulkan tersebut harus dirubah dengan tahapan preprosesing. Adapun data hasil dari tahapan preprosesing seperti berikut:

Tabel 2. Preprosesing Data

\begin{tabular}{ccccccc}
\hline No & Responden & Kehadiran & Tugas & UTS & UAS & Hasil \\
\hline 1 & R1 & Tinggi & Tinggi & Tinggi & Tinggi & Lulus \\
2 & R2 & Tinggi & Tinggi & Tinggi & Tinggi & Lulus \\
3 & R3 & Tinggi & Tinggi & Tinggi & Rendah & Lulus \\
4 & R4 & Tinggi & Rendah & Tinggi & Rendah & Lulus \\
5 & R5 & Tinggi & Tinggi & Tinggi & Rendah & Lulus \\
6 & R6 & Tinggi & Tinggi & Tinggi & Rendah & Lulus \\
7 & R7 & Tinggi & Tinggi & Rendah & Tinggi & Lulus \\
8 & R8 & Tinggi & Tinggi & Tinggi & Tinggi & Lulus \\
9 & R9 & Rendah & Rendah & Rendah & Rendah & Tidak Lulus \\
10 & R10 & Rendah & Rendah & Rendah & Rendah & Tidak Lulus \\
11 & R11 & Tinggi & Tinggi & Rendah & Rendah & Lulus \\
12 & R12 & Tinggi & Tinggi & Rendah & Rendah & Tidak Lulus \\
13 & R13 & Rendah & Rendah & Rendah & Rendah & Tidak Lulus \\
14 & R14 & Tinggi & Tinggi & Tinggi & Rendah & Lulus \\
15 & R15 & Rendah & Rendah & Rendah & Rendah & Tidak Lulus \\
\hline
\end{tabular}

Tabel 2 merupakan data yang sudah dilakukan preprosesing data. Kemudian dari data pada tabel 2 tersebut dapat dilakukan proses klasifikasi menggunakan algoritma C5.0. Kemudian menghitung berapa jumlah kasus, jumlah kasus untuk hasil Lulus, jumlah kasus untuk hasil Tidak Lulus, dan entropy dari semua kasus dan kasus dibagi berdasarkan atribut Variabel Kehadiran, Variabel Tugas, Variabel UTS, dan Variabel UAS. Tehap selanjutnya adalah dilakukan perhitungan gain untuk setiap atribut.

Tabel 3. Perhitungan Node 1

\begin{tabular}{|c|c|c|c|c|c|c|c|}
\hline Node & Atribut & Nilai & Jumlah Kasus / Data Set & Lulus & Tidak Lulus & Entropy & Gain \\
\hline \multirow[t]{13}{*}{1} & & & 15 & 10 & 5 & 0,9183 & \\
\hline & Kehadiran & & & & & & 0,596 \\
\hline & & Tinggi & 11 & 10 & 1 & 0,4395 & \\
\hline & & Rendah & 4 & 0 & 4 & 0 & \\
\hline & Tugas & & & & & & 0,36499 \\
\hline & & Tinggi & 10 & 9 & 1 & 0,469 & \\
\hline & & Rendah & 5 & 1 & 4 & 0,72193 & \\
\hline & UTS & & & & & & 0,51551 \\
\hline & & Tinggi & 8 & 8 & 0 & 0 & \\
\hline & & Rendah & 7 & 2 & 5 & 0,86312 & \\
\hline & UAS & & & & & & 0,18934 \\
\hline & & Tinggi & 4 & 4 & 0 & 0 & \\
\hline & & Rendah & 11 & 6 & 5 & 0,99403 & \\
\hline
\end{tabular}

Berdasarkan hasil dari perhitungan pada di atas, dapat diketahui bahwa Kehadiran memiliki gain yang lebih tinggi dibandingkan dengan gain lainnya yaitu 0,596. Oleh sebab itu, Kehdairan dijadikan sebagai akar dari pohon keputusan. Pada atribut kehadiran yang menjadi akar pohon keputusan terdapat 2 nilai atribut yaitu Tinggi dan Rendah. Untuk nilai atribut Rendah didapatkan hasil keputusan yaitu Tidak Lulus. Sedangkan pada atribut Tinggi masih terdapat 2 keputusan yaitu Lulus dan Tidak Lulus maka proses pembentukan pohon keputusan masih tetap dilanjutkan berdasarkan dengan data berikut

Tabel 4. Data Perhitungan Node 1.1 
JURNAL MEDIA INFORMATIKA BUDIDARMA

Volume 5, Nomor 3, Juli 2021, Page 1166-1172

ISSN 2614-5278 (media cetak), ISSN 2548-8368 (media online)

Available Online at https://ejurnal.stmik-budidarma.ac.id/index.php/mib DOI 10.30865/mib.v5i3.3116

\begin{tabular}{ccccccc}
\hline No & Responden & Kehadiran & Tugas & UTS & UAS & Hasil \\
\hline 1 & R1 & Tinggi & Tinggi & Tinggi & Tinggi & Lulus \\
2 & R2 & Tinggi & Tinggi & Tinggi & Tinggi & Lulus \\
3 & R3 & Tinggi & Tinggi & Tinggi & Rendah & Lulus \\
4 & R4 & Tinggi & Rendah & Tinggi & Rendah & Lulus \\
5 & R5 & Tinggi & Tinggi & Tinggi & Rendah & Lulus \\
6 & R6 & Tinggi & Tinggi & Tinggi & Rendah & Lulus \\
7 & R7 & Tinggi & Tinggi & Rendah & Tinggi & Lulus \\
8 & R8 & Tinggi & Tinggi & Tinggi & Tinggi & Lulus \\
11 & R11 & Tinggi & Tinggi & Rendah & Rendah & Lulus \\
12 & R12 & Tinggi & Tinggi & Rendah & Rendah & Tidak \\
14 & R14 & Tinggi & Tinggi & Tinggi & Rendah & Lulus \\
\hline
\end{tabular}

Kemudian dari data pada tabel 4 untuk perhitungan node 1.1 dilakukan proses yang sama seperti pencarian akar (node 1). Dengan mencari kembali nilai entropy dan gain. Dimana nantinya atribut dengan nilai gain tertinggi akan menjadi akar selanjutnya.

Tabel 5. Perhitungan Node 1.1

\begin{tabular}{|c|c|c|c|c|c|c|c|}
\hline Node & Atribut & Nilai & Jumlah Kasus / Data Set & Lulus & Tidak Lulus & Entropy & Gain \\
\hline 1.1 & \multirow{4}{*}{ Tugas } & & 11 & 10 & 1 & 0,4395 & \multirow{4}{*}{0,16379} \\
\hline & & & & & & & \\
\hline & & Tinggi & 10 & 9 & 1 & 0,469 & \\
\hline & & Rendah & 5 & 1 & 4 & 0,72193 & \\
\hline & \multirow[t]{3}{*}{ UTS } & & & & & & \multirow[t]{3}{*}{0,66785} \\
\hline & & Tinggi & 8 & 8 & 0 & 0 & \\
\hline & & Rendah & 3 & 2 & 1 & 0,9183 & \\
\hline & \multirow[t]{3}{*}{ UAS } & & & & & & \multirow[t]{3}{*}{0,54178} \\
\hline & & Tinggi & 4 & 4 & 0 & 0 & \\
\hline & & Rendah & 7 & 6 & 1 & 0,59167 & \\
\hline
\end{tabular}

Berdasarkan hasil dari perhitungan pada di atas, dapat diketahui bahwa UTS memiliki nilai gain yang lebih tinggi dibandingkan dengan gain lainnya yaitu 0,66785. Oleh sebab itu, UTS dijadikan sebagai akar node 1.1 dari pohon keputusan. Pada atribut UTS yang menjadi akar pohon node 1.1 keputusan terdapat 2 nilai atribut yaitu Tinggi dan Rendah. Untuk nilai atribut Tinggi didapatkan hasil keputusan yaitu Lulus. Sedangkan pada atribut Rendah masih terdapat 2 keputusan yaitu Lulus dan Tidak Lulus maka proses pembentukan pohon keputusan masih tetap dilanjutkan berdasarkan dengan data berikut

Tabel 6. Data Perhitungan Node 1.1.1

\begin{tabular}{ccccccc}
\hline No & Responden & Kehadiran & Tugas & UTS & UAS & Hasil \\
\hline 7 & R7 & Tinggi & Tinggi & Rendah & Tinggi & Lulus \\
11 & R11 & Tinggi & Tinggi & Rendah & Rendah & Lulus \\
12 & R12 & Tinggi & Tinggi & Rendah & Rendah & Tidak \\
& & & & & & Lulus \\
\hline
\end{tabular}

Kemudian dari data pada tabel 6 untuk perhitungan node 1.1.1 dilakukan proses yang sama seperti pencarian akar (node 1.1). Dengan mencari kembali nilai entropy dan gain. Dimana nantinya atribut dengan nilai gain tertinggi akan menjadi akar selanjutnya.

Tabel 7. Perhitungan Node 1.1.1

\begin{tabular}{|c|c|c|c|c|c|c|c|}
\hline Node & Atribut & Nilai & Jumlah Kasus / Data Set & Lulus & Tidak Lulus & Entropy & Gain \\
\hline \multirow[t]{6}{*}{1.1 .1} & \multirow{4}{*}{ Tugas } & & 3 & 2 & 1 & 0,9183 & \\
\hline & & & & & & & 0 \\
\hline & & Tinggi & 3 & 2 & 1 & 0,9183 & \\
\hline & & Rendah & 0 & 0 & 0 & 0 & \\
\hline & \multirow[t]{2}{*}{ UAS } & & & & & & 0,58496 \\
\hline & & Tinggi & 1 & 1 & 0 & 0 & \\
\hline
\end{tabular}


JURNAL MEDIA INFORMATIKA BUDIDARMA

Volume 5, Nomor 3, Juli 2021, Page 1166-1172

ISSN 2614-5278 (media cetak), ISSN 2548-8368 (media online)

Available Online at https://ejurnal.stmik-budidarma.ac.id/index.php/mib

DOI 10.30865/mib.v5i3.3116

\begin{tabular}{|c|c|c|c|c|c|c|c|}
\hline Node & Atribut & Nilai & Jumlah Kasus / Data Set & Lulus & Tidak Lulus & Entropy & Gain \\
\hline & & Rendah & 2 & 2 & 1 & 0,5 & \\
\hline
\end{tabular}

Pada tabel perhitungan node 1.1.1 didapatkan atribut UAS dengan nilai gain tertinggi sebesar 0,58496. Maka dapat dilihat pohon keputusan akhir pada proses klasifikasi pada gambar berikut

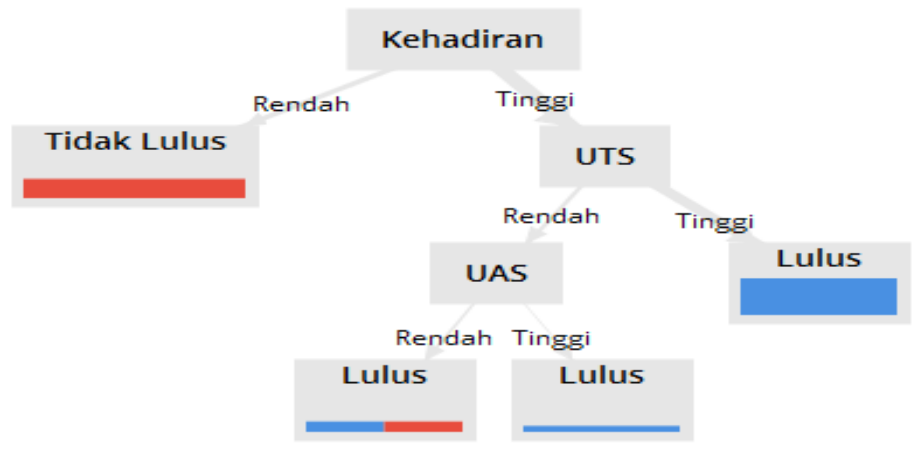

Gambar 1. Pohon Keputusan Akhir

Kemudian setelah didapatkan pohon keputusan pada proses klasifikasi maka selanjutnya melakukan pengujian terhadap hasil yang didapatkan untuk mengukur tingkat akurasi yang didapatkan

Tabel 8. Hasil Akurasi Kinerja Klasifikasi

\begin{tabular}{cccc} 
Akurasi : 93,33\% & \multicolumn{3}{c}{} \\
\hline & True Lulus & True Tidak Lulus & Class Precision \\
\hline Pred. Lulus & 10 & 1 & $90,91 \%$ \\
Pred. Tidak Lulus & 0 & 4 & $100 \%$ \\
Class Recall & $100 \%$ & $80 \%$ & \\
\hline
\end{tabular}

\section{KESIMPULAN}

Berdasarkan dengan penelitian yang dilakukan didapatkan hasil bahwa algoritma C5.0 dapat digunakan untuk memprediksi kelulusan mahasiswa/I pada matakuliah arsitektur sistem komputer. Proses prediksi dilakukan berdasarkan dengan klasifikasi algoritma C5.0 dengan menggunakan atribut Nilai Kehadiran, Nilai Tugas, Nilai UTS dan Nilai UAS. Hasil akhir dari proses klasifikasi algoritma C5.0 adalah pohon keputusan dengan rule didalamnya. Kinerja algoritma C5.0 mendapatkan tingkat akurasi yang tinggi sebesar 93,33\%.

\section{REFERENCES}

[1] E. Buulolo, Data Mining Untuk Perguruan Tinggi, 1st ed. Yogyakarta: Deepublish, 2020.

[2] E. Prasetyo, Data Mining, Konsep Dan Aplikasi Menggunakan Matlab. Yogyakarta: Andi, 2012.

[3] D. Nofriansyah and G. W. Nurcahyo, Algoritma Data Mining Dan Pengujiannya. Yogyakarta: Deepublish, 2017.

[4] A. Novianti and E. Elisa, "Penentuan Aturan Asosiasi Pola Pembelian Pada Minimarket Dengan Algoritma Apriori," Build. Informatics, Technol. sicience, vol. 2, no. 1, pp. 64-70, 2020.

[5] V. Miralda, M. Zarlis, and E. Irawan, "Penerapan Metode K-Means Clustering Untuk Daging Ayam Buras," Build. Informatics, Technol. Sci., vol. 2, no. 2, pp. 91-98, 2020.

[6] C. Hutabarat, "Penerapan Data Mining Untuk Memprediksi Permintaan Produk Kartu Perdana Internet Menggunakan Algoritma C5.0 (Studi Kasus: Vidha Ponsel)," Pelita Inform., vol. 6, no. April, pp. 419-424, 2018.

[7] R. Pratiwi, M. N. Hayati, and S. Prangga, "Perbandingan Klasifikasi Algoritma C5.0 Dengan Classification and Regression Tree (Studi Kasus : Data Sosial Kepala Keluarga Masyarakat Desa Teluk Baru Kecamatan Muara Ancalong Tahun 2019)," BAREKENG J. Ilmu Mat. dan Terap., vol. 14, no. 2, pp. 273-284, 2020.

[8] D. P. Utomo, P. Sirait, and R. Yunis, "Reduksi Atribut Pada Dataset Penyakit Jantung dan Klasifikasi Menggunakan Algoritma C5. 0," Media Inform. Budidarma, vol. 4, no. 4, pp. 994-1006, 2020.

[9] D. P. Utomo and M. Mesran, "Analisis Komparasi Metode Klasifikasi Data Mining dan Reduksi Atribut Pada Data Set Penyakit Jantung," J. Media Inform. Budidarma, vol. 4, no. 2, p. 437, 2020.

[10] T. Permana, A. M. Siregar, A. F. N. Masruriyah, and A. R. Juwita, "Perbandingan Hasil Prediksi Kredit Macet Pada Koperasi," Conf. Innov. Appl. Sci. Technol., vol. 3, no. 1, pp. 737-746, 2020.

[11] R. P. S. Putri and I. Waspada, "Penerapan Algoritma C4.5 pada Aplikasi Prediksi Kelulusan Mahasiswa Prodi Informatika," Khazanah Inform. J. Ilmu Komput. dan Inform., vol. 4, no. 1, p. 1, 2018.

[12] F. Hadi, "Penerapan Data Mining Dalam Menganalisa Pemberian Pinjamana Dengan Menggunakan Metode Algoritma C5 .0 ( Studi Kasus : Koperasi Jasa Keuangan Syariah Kelurahan Lambung Bukik ),” J. KomTekInfo, vol. 4, no. 2, pp. 214-223, 2017.

[13] I. P. Sari and R. Harman, "Decission Tree Technique Dalam Menentukan Penjurusan Siswa Menengah Kejuruan," J. Inf. Syst. Res., vol. 1, no. 4, pp. 296-304, 2020.

[14] N. Mayasari, "Comparison of Support Vector Machine and Decision Tree in Predicting On-Time Graduation (Case 
Study : Universitas Pembangunan Panca Budi)," Int. J. Recent Trends Eng. Res., vol. 2, no. 12, pp. 140-151, 2016.

[15] D. Dalbergio, M. N. Hayati, and Y. N. Nasution, "Klasifikasi Lama Studi Mahasiswa Menggunakan Metode C5.0 pada Studi Kasus Data Kelulusan Mahasiswa Fakultas Matematika Dan Ilmu Pengetahuan Alam Universitas Mulawarman Tahun 2017,” Pros. Semin. Nas. Mat. Stat. dan Apl. 2019, vol. 1, no. 1, pp. 36-42, 2019.

[16] A. C. Wijaya, N. A. Hasibuan, and P. Ramadhani, "Implementasi Algoritma C5 . 0 Dalam Klasifikasi Pendapatan Masyarakat ( Studi Kasus : Kelurahan Mesjid Kecamatan Medan Kota )," Inf. dan Teknol. Ilm., vol. 13, pp. 192-198, 2018.

[17] M. Pardede, E. Buulolo, and E. Ndruru, "Implementasi Algoritma C5.0 Pada Kelulusan Peserta Ujian Kemahiran Berbahasa Indonesia (Ukbi) Pada Balai Bahasa Sumatera Utara," KOMIK (Konferensi Nas. Teknol. Inf. dan Komputer), vol. 3, no. 1, pp. 64-72, 2019. 